\title{
ANALISIS GULA DARAH UNTUK MENDIAGNOSIS PENYAKIT DIABETES MELITUS (DM)
}

\author{
Ni Komang Ayuni \\ Universitas Pendidikan Ganesha \\ Singaraja, Indonesia \\ e-mail: ayunikm9n@gmail.com
}

\begin{abstract}
Abstrak
Penelitian ini bertujuan untuk mengetahui (1) cara menganalisis gula darah untuk mendiagnosis penyakit Diabetes Melitus (DM), (2) persentase penderita positif DM di Laboratorium Patologi Klinik RSUD Buleleng. Subyek penelitian ini adalah serum darah dan obyek penelitian ini adalah kadar gula darah dan persentase penderita positif DM yang memeriksakan gula darahnya di Laboratorium Patologi Klinik RSUD Buleleng. Metode penelitian ini adalah deskriptif, data tentang kadar gula darah penderita Diabetes Melitus (DM) dianalisis secara deskriptif. Hasil penelitian menunjukkan (1) Diagnosis penyakit Diabetes Melitus dilakukan dengan melakukan pemeriksaan BSN dan BS 2 Jam PP. Analisis gula darah di Laboratorium Patologi Klinik RSUD Buleleng dilakukan dengan pemeriksaaan serum darah dengan menggunakan alat Spektrofotometri BTS 310, (2) Dari 249 pasien yang memeriksakan kadar gula darahnya di Laboratorium Patologi Klinik RSUD Buleleng dari tanggal 2 Mei-30 Juni 2005 ternyata 187 orang $(75,1 \%)$ menderita penyakit positif DM.
\end{abstract}

Kata kunci: Analisis, Kadar, Gula Darah, Penderita, Diabetes Melitus

\begin{abstract}
This study aims to determine (1) how to analyze blood sugar to diagnose Diabetes Mellitus (DM), (2) the percentage of DM positive sufferers in the Clinical Pathology Laboratory of Buleleng Hospital. The subject of this study was blood serum and the object of this study was blood sugar levels and the percentage of positive DM patients who checked their blood sugar at the Clinical Pathology Laboratory of Buleleng Hospital. This research method is descriptive, data on blood sugar levels of people with Diabetes Mellitus (DM) were analyzed descriptively. The results showed (1) Diagnosis of Diabetes Mellitus was carried out by examining the BSN and BS 2 Hours PP. Blood sugar analysis at the Clinical Pathology Laboratory of Buleleng Hospital was carried out by examining blood serum using BTS 310 Spectrophotometry, (2) Of the 249 patients who had their blood sugar levels checked at the Clinical Pathology Laboratory of Buleleng Hospital from 2 May-30 June 2005, 187 people ( 75.1\%) suffer from DM positive disease.
\end{abstract}

Keywords: Analysis of blood sugar levels, diabetes mellitus sufferers.

\section{Pendahuluan}

Penyakit Diabetes Melitus (DM) adalah penyakit metabolik yang biasanya bersifat herediter dengan tanda-tanda hiperglikemia dan glukosuria disertai dengan adanya gejala klinik akut maupun kronik yang disebabkan oleh kurangnya insulin efektif di dalam tubuh. Gangguan primer terletak pada metabolisme karbohidrat yang disertai juga gangguan metabolisme lemak dan protein. Salah satu penyebab terjadinya gangguan metabolisme tersebut adalah karena adanya komplikasi dari penyakit diabetes (Widyaguna, Slamet dkk, 1998: 12).

Penyakit Diabetes Melitus (DM) sekarang mulai banyak muncul di Indonesia. Sejalan dengan berkembangnya ilmu pengetahuan dan teknologi serta perubahan prilaku hidup seharihari yang kurang sehat, dikhawatirkan masalah kesehatan terutama penyakit diabetes melitus akan mengalami peningkatan. Prilaku yang dimaksud adalah seperti pola makan dan kebiasaan makan yang salah (kadar gula dan lemak yang tinggi), stress psikologis akibat cara hidup yang sangat sibuk dengan pekerjaan dan kurang olahraga, di samping itu bisa juga disebabkan oleh adanya kerusakan pada pankreas. Pada pankreas terdapat sel-sel Alfa dan Beta yang 
berkumpul membentuk pulau Langerhans yang menghasilkan hormon. Sel Alfa menghasilkan hormon glukagon, hormon ini dapat menimbulkan hiperglikemia dengan cara meningkatkan kadar gula yang ada di dalam darah yaitu dengan cara memobilisasi cadangan gula yang ada di dalam hati. Gula ini kemudian dicurahkan ke dalam darah akibatnya terjadi penumpukan gula di dalam darah sehingga menyebabkan hiperglikemia. Sel Beta Pulau Langerhans menghasilkan hormon insulin, hormon ini berperan dalam metabolisme karbohidrat dan juga lemak normal. Hipersekresi atau produksi hormon insulin berlebih akan menyebabkan hipoglikemi. Adanya kelainan atau kerusakan pada sel Beta Pulau Langerhans akan menyebabkan Hiposekresi atau produksi hormon insulin berkurang sehingga akan mengakibatkan hiperglikemi yang kemudian disusul dengan terjadinya penyakit DM (Nala, Ngurah 1991: 12).

Penyakit ini menyerang tidak membedakan jenis kelamin maupun umur. Diperkirakan ada sebanyak $3 \%$ lebih dari seluruh penduduk mengidap penyakit ini. Jadi di seluruh Indonesia ada sekitar 5-6 juta penduduk yang terkena penyakit DM ini. Di antara pengidap penyakit ini kurang lebih 20\% termasuk kategori DM Tipe I (tubuh pengidap tidak menghasilkan hormon insulin sama sekali). Sedangkan sebagian besar lainnya, 80\% termasuk kategori DM Tipe II (tubuh pengidap masih mampu memproduksi hormon insulin tetapi jumlahnya tidak memadai).

Di negara sedang berkembang seperti Indonesia angka ini mencapai 95\% dan di negara maju seperti Amerika Serikat sebesar $93 \%$. Kemungkinan besar penyakit DM Tipe I dan II akan terus bertambah setiap tahun, hal ini terutama disebabkan oleh perubahan dan gaya hidup masyarakat. Perubahan tersebut terutama pada menu makanan, gaya hidup dari yang banyak bergerak menjadi kurang bergerak (aktifitas fisik), dan perubahan lingkungan hidup yang sudah banyak tercemar sehingga daya tahan tubuh akan menurun terhadap penyaki (Nala, Ngurah 1991: 7-8). Sebelum penemuan insulin pada tahun 1921, hampir semua penderita diabetes ini meninggal dunia. Kemungkinan, di masa mendatang penyakit ini akan disembuhkan oleh transplantasi pancreas. Di Indonesia jenis ini berjumlah sekitar $10 \%$ dari seluruh kasus diabetes. Prof. Dr. Utojo Sukaton menyatakan bahwa meningkatnya kasus diabetes tipe II di Indonesia, sebagian disebabkan oleh pengaruh kebudayaan dan makanan dari dunia barat. Hal ini dikuatkan oleh Dr. H. E. Lebovitz dari pusat ilmu kesehatan State University of New York, AS. Jenis Diabetes inilah yang sangat dominan dalam kasus-kasus diabetes di Indonesia (Albert M, 1996: 204).

Apabila penyakit DM ini tidak ditanggulangi secara baik maka dikhawatirkan akan terjadi komplikasi yang lebih lanjut seperti gangguan pada organ tubuh yang lain dan akan mengancam kehidupan. Tindakan yang dilakukan untuk menanggulangi penyakit DM ini adalah dengan pemberian OAD yang diberikan oleh para pihak medis. Namun dengan tindakan atau usaha yang telah diberikan tersebut tidaklah mencukupi dalam penanggulangan penyakit ini, sehingga disini perlu disarankan usaha-usaha seperti: Penyuluhan Kesehatan Masyarakat (PKM) tentang tata cara hidup sehat baik itu prilaku hidup sehari-hari seperti perencanaan makanan (diet) dan perencanaan aktifitas fisik yang teratur seperti berolah raga secara teratur. PKM bisa dilakukan melalui perorangan (antara dokter dengan penderita), media elektronik (TV, kaset vidio), media cetak (koran, majalah, poster).

Berdasarkan catatan medik Rumah Sakit Umum Buleleng dalam dua bulan terakhir dari bulan Mei sampai Juni tercatat pasien yang dirawat dengan penderita diabetes melitus cukup tinggi. Dengan semakin banyaknya penderita DM yang muncul di masyarakat serta terjadinya komplikasi yang ditimbulkan dianggap berbahaya dan dapat menyulitkan hidup selanjutnya sehingga informasi tentang penyakit Diabetes Melitus (DM) perlu diketahui dan dipahami oleh masyarakat. Oleh karena sangat penting dan menarik tentang informasi penyakit DM serta kompliksi yang ditimbulkan sehingga dalam penelitian ini penulis mencoba menganalisis cara mendiagnosis penyakit DM dan ingin mengetahui persentase penderita positif DM di RSUD Buleleng.

\section{Metode}

Penelitian ini adalah penelitian deskriptif, yang bertujuan untuk menggambarkan atau mendeskripsikan tentang analisis gula darah dalam mendiagnosis penyakit Diabetes Melitus (DM) dan untuk mengetahui persentase pasien yang positif DM yang memeriksakan dirinya di Laboratorium Patologi Klinik RSUD Buleleng. Di dalam penelitian ini subjek yang digunakan adalah serum darah dari 249 pasien yang diduga menderita penyakit DM, sedangkan objek penelitian ini adalah (1) kadar gula darah, (2) persentase pasien yang positif DM dari pasien yang didugamenderita penyakit DM yang memeriksakan gula darahnya pada tanggal 2 Mei-30 
Juni 2005 di Laboratorium Patologi Klinik RSUD Buleleng. Untuk dapat melakukan pemeriksaan maka diperlukan persiapan. Persiapan ini meliputi persiapan instrumen yang berupa Spektrofotometri BTS 310, sentrifuges, rotator, clinipete, sedangkan untuk persiapan bahannya berupa reagen glukosa, reagaen standar glukosa dan serum darah. Darah yang diperoleh dari pasien diolah dulu menjadi serum. Setelah didapat serum barulah bisa dilakukan pemeriksaan. Dari pemeriksaan itu maka diperoleh data kadar gula darah dari pasien yang diduga menderita penyakit DM, yang selanjutnya data ini dianalisis secara deskriptif.

Tahap Persiapan dari penelitian ini yaitu: a) Persiapan Peneliti yaitu peneliti memerlukan jas laboratorium, sarung tangan (hand scoon); b) Persiapan alat dan bahan yang meliputi: Tabung reaksi, clinipete $10 \mu \mathrm{L}$ dan $1000 \mu \mathrm{L}$, Spektrofotometri BTS 310, sampel yang berupa serum darah, reagen glukosa, reagen standar glukosa, aquades, rotator, sentrifuges; $c$ ) Mengumpulkan pustaka-pustaka yang digunakan dalam penelitian ini; d) Mengumpulkan informasi-informasi yang mendukung penelitian. Tahap Pengambilan Darah dalam penelitian ini yaitu Darah diambil dari pasien yang memeriksakan gula darahnya di Laboratorium RSUD Buleleng selama 2 bulan. Selanjutnya tahap Pengolahan Darah Menjadi Serum yaitu Darah dibiarkan beku, disentrifus selama 15-20 menit kemudian serum dipisahkan dari bekuan. Tahap terakhir yaitu Tahap Analisis Serum sebagai berikut: a) Mempersiapkan reagen glukosa, sample (serum darah) dan reagen standar glukosa pada temperatur ruangan serta menyediakan 3 tabung reaksi; b) Memipet dan memasukkan ke dalam tabung reaksi masingmasing meliputi: 1)) Tabung 1 diisi reagen glukosa $1000 \mu \mathrm{L}$, 2) Tabung 2 diisi reagen standar glukosa $10 \mu \mathrm{L}$ dan reagen glukosa $1000 \mu \mathrm{L}$, 3)) Tabung 3 diisi sampel serum darah $10 \mu \mathrm{L}$ dan reagen glukosa $1000 \mu \mathrm{L}$; c) Ketiga tabung ini dicampur baik-baik dan diinkubasi selama 10 menit pada suhu kamar atau selama 5 menit pada suhu $37^{\circ} \mathrm{C}$; d) Absorbansi tabung 2 dan 3 dibaca pada alat spektrofotometri BTS 310 padapanjang gelombang $546 \mathrm{~nm}$ terhadap tabung 1 pada program 17. Dengan melakukan pemeriksaan tersebut maka diperoleh data kadar gula darah.

\section{Hasil dan Pembahasan}

Hasil analisis kadar gula darah yang dilakukan dengan pemeriksaan serum darah di Laboratorium Patologi Klinik RSUD Buleleng selama 2 bulan (2 Mei-30 Juni) dengan alat spektrofotometri disajikan dalam Tabel 1 dan 2 dibawah:

Tabel 1. Data Jumlah Pasien yang Didiagnosis Menderita DM Selama 2 Bulan

\begin{tabular}{lc}
\hline \multicolumn{1}{c}{ Keetrangan } & Jumlah Orang/Pasien \\
\hline BSN $(<100 \mathrm{mg} / \mathrm{dL})$ & 58 orang/pasien \\
BS 2 Jam PP $(<125 \mathrm{mg} / \mathrm{dL})$ & 58 orang/pasien \\
BSN $(>100 \mathrm{mg} / \mathrm{dL})$ & 191 orang/pasien \\
BS 2 Jam PP $(>125 \mathrm{mg} / \mathrm{dL})$ & 191 orang/pasien \\
\hline
\end{tabular}

Tabel 2. Data Hasil Diagnosis Penderita Positif DM dan Negatif DM Selama 2 Bulan

\begin{tabular}{cccc}
\hline Bulan & Jumlah pasien & Pasien negatif DM & Pasien positif DM \\
\hline Mei & 124 & $33(26,6 \%)$ & $91(73,4 \%)$ \\
Juni & 125 & $29(23,2 \%)$ & $96(76,8 \%)$ \\
\hline & Total 249 & Rata-rata 24,9\% & Rata-rata 75, 1\% \\
\hline
\end{tabular}

Untuk mengetahui kadar gula darah dalam diri atau seorang pasien maka perlu dilakukan suatu analisis terhadap darah pasien tersebut. Analisis ini dapat dilakukan dengan cara melakukan pemeriksaan terhadap gula darah pada pasien. Bahan yang dianalisis adalah berupa serum (plasma). Seperti dikatahui bahwa darah tersebut terdiri dari bagian cair yaitu plasma (serum) dan bagian padat yaitu sel-sel darah. Plasma ini terdiri dari air dan zat-zat yang larut dalam air, antara lain: protein, karbohidrat, asam amino, urea, kreatinin, vitamin dan pigmen. Sedangkan sel-sel darah terdiri dari eritrosit (sel darah merah), leukosit (sel darah putih), dan trombosit (keeping darah) (Kimia Forensik, 2005: 1). Melihat komponen yang ada dalam darah tersebut maka kadar gula darah yang ada dalam plasma dapat diperiksa dengan alat Spektrofotometri BTS 310. 
Kompleks ini terjadi karena pencampuran serum yang mengandung glukosa dengan reagen untuk uji glukosa. Pengukuran kompleks ini dilakukan dengan alat Spektrofotometri pada panjang gelombang $546 \mathrm{~nm}$ program 17. Dengan melakukan pemeriksaan ini maka dapat diketahui kadar gula darah yang dapat dibaca pada alat Spektrofotometri BTS 310 tersebut. Dari hasil pemeriksaan itu dapat diketahui pasien yang positif DM dan yang negatif DM dengan cara membandingkan hasil pemeriksaan dengan nilai normalnya. Pasien dikatakan menderita positif DM apabila hasil pemeriksaan gula darah puasa (BSN) diatas nilai normal (>100 $\mathrm{mg} / \mathrm{dL}$ ) dan hasil pemeriksaan gula darah 2 jam PP juga diatas nilai normal ( $>125 \mathrm{mg} / \mathrm{dL})$, sedangkan pasien dikatakan negatif DM apabila hasil pemeriksaan kadar gula darah puasa (BSN) dibawah nilai normal $(<100 \mathrm{mg} / \mathrm{dL})$ dan hasil pemeriksaan gula darah 2 jam PP juga dibawah nilai normal $(<125 \mathrm{mg} / \mathrm{dL}$. Apabila hasil pemeriksaan gula darah puasa diatas normal dan hasil pemeriksaan 2 jam PP dibawah harga normal, maka perlu melakukan pemeriksaan ulang.

Dari 249 pasien yang memeriksakan kadar gula darahnya di Laboratorium Patologi Klinik RSUD Buleleng selama 2 bulan (Mei-Juni) ternyata didapatkan penderita positif DM adalah sebesar 187 orang/pasien (75,1\%).

Dengan melihat persentase tersebut dapat dikatakan bahwa cukup banyak penderita DM yang memeriksakan dirinya di Laboratorium Patologi Klinik RSUD Buleleng.

\section{Simpulan dan Saran}

Dari hasil dan pembahasan diatas dapat disimpulkan bahwa: 1) Analisis gula darah dapat dilakukan dengan pemeriksaan serum darah pasien dengan menggunakan alat Spektrofotometri BTS 310 program 17. Metode yang digunakan adalah oxidase peroksida. Diagnosis penyakit DM dilakukan dengan membandingkan hasil pemeriksaan gula darah dengan nilai standar. Apabila hasil pemeriksaan gula darah diatas nilai normal maka pasien dinyatakan positif DM sedangkan untuk hasil pemeriksaan dibawah nilai normal maka pasien dinyatakan negatif DM, 2) Dari 249 pasien yang memeriksakan kadar gula darahnya selama 2 bulan (2 Mei - 30 Juni 2005) di Laboratorium Patologi Klinik RSUD Buleleng ternyata 187 pasien $(75,1 \%)$ positif menderita penyakit DM.

Dari hasil penelitian ini dapat disarankan hal-hal sebagai berikut: 1) Masyarakat yang didiagnosis menderita penyakit Diabetes Melitus (DM) agar segera memeriksakan gula darahnya, sehingga bila terjadi hiperglikemia atau kadar gula darah meningkat bisa segera ditindak lanjuti; 2) Perlunya diadakan penyuluhan tentang informasi kesehatan serta komplikasi yang ditimbulkannya sehingga masyarakat bisa lebih waspada.

\section{Daftar Pustaka}

Albert, 1996. Menuju Gaya Hidup Sehat. Jakarta: PT. Gramedia Pustaka Utama.

Baron, D.N. Patologi Kilinik. Edisi 4. Terjemahan Petrus Andrianto \& Johannes Gunawan. A Short Text Book of Chemical Pathologi. Jakarta: EGC.

Bence, Richard. 1990. Endodontik Klinik. Jakarta: Universitas Indonesia.

Departemen Kesehatan. 1994. Diagnosa Penyakit Dalarn. Denpasar: Universitas Udayana.

Matthew Hoffman, dkk. 1996. Bebas dari Penyakit. Jakarta: PT. Gramedia Pustaka Utama.

Nala, Ngurah. 1996. Usada Kencing Manis. Denpasar: Upada Sastra.

Suparto, H 1997. Sehat Menjelang U ia Senja. Bandung: PT. Remaja Rosdakarya.

Widyaguna, Slamet I Wayan, dkk 1998. Asuhan Keperawatan Keluarga I Made Dana Dengan Kasus Tuberculosis + Diabetes A1elitus Di Banjar Tenten Desa Pemecutan Kelod Kecamatan Denpasar Barat. Makalah (Tidak Diterbitkan) Sekolah Perawat Kesehatan PPNI. Denpasar.

Wijayaputra, Ngurah. Penentuan Golongan Darah dan DNA Typing dari Sampel Darah, Rambut. Air Liur dan Cairan Mani untuk Kepentingan Forensik. Denpasar: Pusat Laboratorium Forensik Cabang Denpasar. 